\title{
Lithium Amidotrihydroborate, a Powerful New Reductant. Transformation of Tertiary Amides to Primary Alcohols.
}

\section{Citation}

Myers, Andrew G., Bryant Yang, and David Kopecky. 1996. Lithium Amidotrihydroborate, a Powerful New Reductant. Transformation of Tertiary Amides to Primary Alcohols. Tetrahedron Letters 37, no. 21: 3623-3626.

\section{Published Version}

http://dx.doi.org/10.1016/0040-4039(96)00652-1

\section{Permanent link}

http://nrs.harvard.edu/urn-3:HUL.InstRepos:4725865

\section{Terms of Use}

This article was downloaded from Harvard University's DASH repository, and is made available under the terms and conditions applicable to Other Posted Material, as set forth at http:// nrs.harvard.edu/urn-3:HUL.InstRepos:dash.current.terms-of-use\#LAA

\section{Share Your Story}

The Harvard community has made this article openly available.

Please share how this access benefits you. Submit a story.

\section{Accessibility}




\title{
Lithium Amidotrihydroborate, a Powerful New Reductant. Transformation of Tertiary Amides to Primary Alcohols.
}

\author{
Andrew G. Myers, * Bryant H. Yang, and David J. Kopecky \\ Division of Chemistry and Chemical Engineering \\ California Institute of Technology, Pasadena, CA 91125
}

\begin{abstract}
Lithium amidotrihydroborate $\left(\mathrm{LiH}_{2} \mathrm{NBH}_{3}, \mathrm{LAB}\right)$ is a new and highly nucleophilic reducing agent that is easily prepared by deprotonation of the commercial reagent borane-ammonia complex $\left(\mathrm{H}_{3} \mathrm{NBH}_{3}\right)$ with $n$-BuLi in tetrahydrofuran (THF) at $0^{\circ} \mathrm{C}$. LAB is found to be a superior reagent for the transformation of tertiary amides into the corresponding primary alcohols.

Copyright $\odot 1996$ Elsevier Science Lid
\end{abstract}

There are few reagents that will selectively transform a tertiary amide into the corresponding primary alcohol. Highly nucleophilic metal hydride reagents will add to a tertiary amide to form a tetrahedral intermediate that can break down by cleavage of the $\mathrm{CN}$ bond to form an aldehyde (leading to the primary alcohol) or by cleavage of the $\mathrm{CO}$ bond, providing a pathway for the formation of a tertiary amine. Most metal

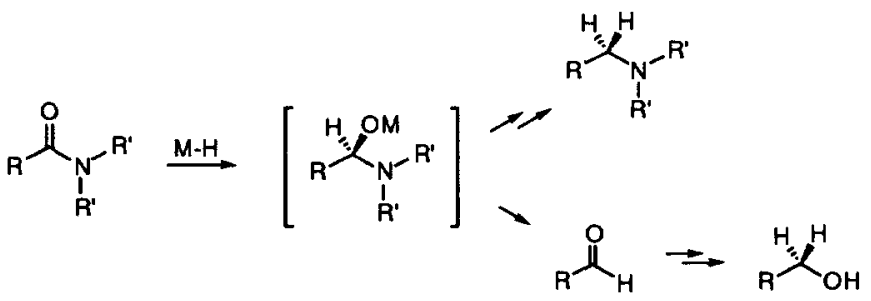

hydride reagents, e.g., lithium aluminum hydride ${ }^{1}$ or diborane, ${ }^{2}$ form the tertiary amine product selectively. For this reason, it is often difficult to convert a tertiary amide into the corresponding primary alcohol, a useful synthetic transformation. Important exceptions to this trend are lithium triethylborohydride ( $\mathrm{LiBHEt}_{3}$, "superhydride"), developed by Brown and co-workers, ${ }^{3}$ and the metal amide-borane complexes introduced by Hutchins et al. and developed extensively by Singaram and co-workers. ${ }^{4}$ Our interest in this problem arose from studies of the diastereoselective alkylation of pseudoephedrine amides, where we required a method to transform the alkylated products into primary alcohols by the reductive cleavage of the pseudoephedrine auxiliary (see Table 1). ${ }^{5}$ We found that alkylated pseudoephedrine amides were inert toward lithium triethylborohydride. Results with the lithium pyrrolidide-borane complex $\left[\mathrm{Li}\left(\mathrm{CH}_{2}\right)_{4} \mathrm{NBH}_{3}, \mathrm{LPT}\right]$ of Singaram et al. ${ }^{\star c, d}$ were more promising. For example, reduction of the amide 1 ( $\geq 99 \%$ de) with LPT afforded the corresponding primary alcohol in $88 \%$ yield and $\geq 95 \%$ ee. ${ }^{6}$ However, when we attempted the reduction of the amide 2 ( $\geq 99 \%$ de) with LPT, we found that the product alcohol was formed with low optical purity (33\% ee, $85 \%$ yield). Remarkably, the major enantiomer produced in this transformation had the inverted configuration at 
the $\alpha$-stereogenic center. We speculated that this product arose by enolization of the intermediate aldehyde (followed by enantioselective protonation and reduction) and undertook a study of alternative reagents to accomplish this reduction enantioselectively.

We have found that the reagent lithium amidotrihydroborate $\left(\mathrm{LiH}_{2} \mathrm{NBH}_{3}, \mathrm{LAB}\right)$ is a highly nucleophilic hydride source that is ideally suited for the transformation of tertiary amides to primary alcohols. Although LAB has been the subject of two prior computational studies, "to our knowledge it had not been prepared in the laboratory prior to this study. ${ }^{5} \mathrm{LAB}$ is easily prepared in situ by the deprotonation of borane-ammonia complex with $n$-butyllithium (1.0 equiv) in THF at $0^{\circ} \mathrm{C}$. Evidence that this reaction produces the title compound comes from ${ }^{1} \mathrm{H}$-decoupled ${ }^{11} \mathrm{~B}$ NMR spectroscopy, where a sharp singlet resonating at $-22 \mathrm{ppm}\left(\mathrm{BF}_{3}{ }^{\bullet} \mathrm{OEt}_{2}\right.$ reference) is observed. This value corresponds well with known amide-borane complexes ${ }^{4 b}$ (but not, e.g., with $\mathrm{LiBuBH}_{3}$, which resonates at $-29 \mathrm{ppm}){ }^{8}$ In addition, when the solid borane-ammonia reagent and neopentyllithium were combined in THF- $d_{8}$ at $23^{\circ} \mathrm{C}$, the same singlet at $-22 \mathrm{ppm}$ was observed in the " B NMR spectrum and neopentane was formed cleanly $\left({ }^{13} \mathrm{C}\right.$ NMR). The LAB precursor, borane-ammonia complex, ${ }^{9}$ is a commercial solid that is moderately air stable (e.g., it can be weighed on the bench-top). As illustrated by the examples in Table 1,

Table 1. Use of LAB in the Reduction of Alkylated Pseudoephedrine Amides to Primary Alcohols ${ }^{\mathrm{a}}$

(n)

${ }^{3}$ Reactions run with LAB $\left(4.0-4.5\right.$ equiv) generated in situ at $0{ }^{\circ} \mathrm{C}$. ${ }^{b}$ Substrates $1,2,4$, and 5 were $\geq 99 \%$ de. Substrate 3 was $98 \%$ de, and substrate 6 was $\geq 95 \%$ de. 
$\mathrm{LAB}$ efficiently reduces alkylated pseudoephedrine amides to the corresponding primary alcohols with little to no epimerization of the $\alpha$-stereocenter. Typically, a two-fold excess of LAB (4 equiv total) is employed in the reaction. Fewer equivalents favor the formation of the tertiary amine by-product, but with $\geq 4$ equiv of LAB only $1-2 \%$ of tertiary amine is observed. In comparison with LPT, LAB reductions are much faster. In addition, LAB is, by far, the superior reagent for the selective reduction of hindered tertiary amides to primary alcohols. For example, substrate 4 is reduced by LAB within $9 \mathrm{~h}$ at $23{ }^{\circ} \mathrm{C}$ to furnish the corresponding alcohol (88\% yield, $\geq 95 \%$ ee), while LPT required elevated temperatures to accomplish the same transformation $\left(11 \mathrm{~h}, 66^{\circ} \mathrm{C}\right.$, $80 \%$ yield, $\geq 95 \%$ ee). More dramatically, the highly hindered amide 5 is reduced with LAB in refluxing THF ( $12 \mathrm{~h}, 91 \%$ yield, $\geq 95 \%$ ee) whereas 5 is essentially inert to LPT ( $5 \%$ yield of alcohol after $12 \mathrm{~h}$ at $66^{\circ} \mathrm{C}$ ). The reduction of the $\beta$-alkoxy amide 3 with LPT was complicated by $\beta$-elimination of benzyl alcohol (45\% yield of alcohol, $91 \%$ ee), whereas LAB reduction of 3 proceeded cleanly ( $88 \%$ yield, 93\% ee). This result, coupled with our observations on the reduction of amide 2, suggest that $L A B$ has a lesser tendency to effect base-induced side reactions than does LPT.

In studies of the reduction of other tertiary amides to primary alcohols (Table 2), we find LAB to be a superior reagent. $N, N$-Diethyldodecanamide formed 1 -dodecanol in $94 \%$ yield $\left(1.3 \mathrm{~h}\right.$ at $\left.23{ }^{\circ} \mathrm{C}\right)$ with $\mathrm{LAB}$, whereas LPT is reported to give the tertiary amine, $N, N$-diethyldodecanamine, in $71 \%$ yield under similar conditions. ${ }^{4 c}$ Even the hindered 1-adamantanecarboxylic acid $N, N$-diethylamide (entry 2) is reduced to the primary alcohol (88\% yield) with LAB. In exploring the limits of tertiary amide reductions with $\mathrm{LAB}$, we find that substantial amounts of tertiary amine by-products are formed with $N, N$-diisopropylamides as substrates (entries 3 and 4, Table 2). This is in keeping with Hutchins' observations that substrates with $\mathrm{N}$-substituents of increasing steric demand tend to favor formation of the tertiary amine with sodium

Table 2. Use of LAB for the Reduction of Tertiary Amides to Primary Alcohols

\begin{tabular}{|c|c|c|c|c|c|}
\hline Entry & Substrate & $\begin{array}{l}\text { Temp } \\
\left({ }^{\circ} \mathrm{C}\right)\end{array}$ & $\begin{array}{l}\text { Time } \\
\text { (h) }\end{array}$ & $\begin{array}{l}\text { Isol Yield } \\
\text { Alcohol (\%) }\end{array}$ & $\begin{array}{c}\text { Isol Yield } \\
3^{\circ} \text { Amine (\%) }\end{array}$ \\
\hline 1 & $\begin{array}{c}\mathrm{CH}_{3}\left(\mathrm{CH}_{2}\right)_{10} \mathrm{CONEt}_{2} \\
\mathrm{CONE}_{3}\end{array}$ & 23 & 1.3 & 94 & $<5$ \\
\hline 2 & & 23 & 10.0 & 88 & 8 \\
\hline 3 & $\mathrm{CH}_{3}\left(\mathrm{CH}_{2}\right)_{10} \mathrm{CON}(i-\mathrm{P})_{2}$ & 23 & 6.0 & 68 & 28 \\
\hline 4 & & 66 & 1.7 & 47 & 51 \\
\hline
\end{tabular}


dimethylamidotrihydroborate ${ }^{4 a}$ as reductant. The fact that the $N, N$-diisopropylamides of entries 3 and 4 are reduced at all with LAB is testimony to the high nucleophilicity of this reagent; lithium triethylborohydride, for example, does not react with $N, N$-diisopropylamides. ${ }^{3}$

In summary, we have demonstrated that LAB is a highly nucleophilic hydride source that is easily pre-pared from readily available, commercial materials. Its efficacy for the particular application at hand, the selective reduction of a tertiary amide to the corresponding alcohol, appears to be superior to any existing reagent. It is anticipated that $\mathrm{LAB}$ will find use as a nucleophilic hydride source in many other applications as well.

\section{Experimental Procedure for the Reduction of 1-Adamantanecarboxylic Acid N.N-diethylamide}

A solution of $n$-butyllithium in hexanes $(2.47 \mathrm{M}, 2.27 \mathrm{~mL}, 5.60 \mathrm{mmol}, 4.00$ equiv) was added to a suspension of borane-ammonia complex $\left(90 \%, 0.197 \mathrm{~g}, 5.74 \mathrm{mmol}, 4.10\right.$ equiv) in tetrahydrofuran $(5.0 \mathrm{~mL})$ at $0{ }^{\circ} \mathrm{C}$. The resulting clear yellow solution was stirred at $0{ }^{\circ} \mathrm{C}$ for $5 \mathrm{~min}$, at $23{ }^{\circ} \mathrm{C}$ for $5 \mathrm{~min}$, then was cooled to $0^{\circ} \mathrm{C}$. A solution of 1 adamantanecarboxylic acid $N, N$-diethylamide $(0.330 \mathrm{~g}, 1.40 \mathrm{mmol}, 1$ equiv) in tetrahydrofuran $(2.0 \mathrm{~mL})$ was added to the cold hydride solution via cannula, and the transfer was quantitated with $30.5-\mathrm{mL}$ portions of tetrahydrofuran. The reaction mixture was warmed to $23^{\circ} \mathrm{C}$ and was held at that temperature for $10 \mathrm{~h}$, then was cooled to $0^{\circ} \mathrm{C}$. Excess hydride was quenched by the slow, dropwise addition of aqueous hydrochloric acid solution $(3 \mathrm{~N}, 5 \mathrm{~mL})$. The reaction mixture was diluted with more aqueous hydrochloric acid solution $(3 \mathrm{~N}, 15 \mathrm{~mL})$, and brine $(15 \mathrm{~mL})$, then was extracted with ether $(4 \times 15 \mathrm{~mL})$. The ether extracts were concentrated, and the solid residue was dissolved in a smaller volume of ether $(2 \mathrm{~mL})$ and the solution was stirred with aqueous sodium hydroxide solution $(2 \mathrm{~N}, 60 \mathrm{~mL})$ for $2.5 \mathrm{~h}$ at $23^{\circ} \mathrm{C}$. More ether $(20 \mathrm{~mL})$ was added and the layers were separated. The aqueous layer was saturated with solid sodium chloride, then was extracted with ether $(3 \times 20 \mathrm{~mL})$. The combined organic extracts were washed with brine $(5 \mathrm{~mL})$, dried over sodium sulfate, and concentrated. The residue was purified by flash column chromatography (37:63:2 ether-petroleum ether-triethylamine) to afford 1-adamantanemethanol (206 mg, 88\%) as a white solid, $\mathrm{mp} 114-115^{\circ} \mathrm{C}$ (lit. $\mathrm{mp}^{10} 115^{\circ} \mathrm{C}$ ). Anal. Calcd for $\mathrm{C}_{11} \mathrm{H}_{18} \mathrm{O}: \mathrm{C}, 79.46, \mathrm{H}, 10.91$. Found: $\mathrm{C}, 79.46$, H, 10.94 .

\section{References and Notes}

(1) (a) Uffer, H.; Schlittler, E. Helv. Chim. Acta 1948, 31, 1397. (b) Gaylord, N. G. Reductions with Complex Metal Hydrides Wiley-Interscience: New York, 1956, p. 544-592. (c) Zabicky, J., Ed. The Chemistry of Amides WileyInterscience: New York, 1970, p. 795-801.

(2) (a) Brown, H. C.; Heim, P. J. Am. Chem. Soc. 1964, 86, 3566. (b) Brown, H. C.; Narasimhan, S.; Choi, Y. M. Synthesis 1981, 441. (c) Brown, H. C.; Narasimhan, S.; Choi, Y. M. Synthesis 1981, 996.

(3) Brown, H. C.; Kim, S. C. Synthesis 1977, 635.

(4) (a) Hutchins, R. O.; Learn, K.; El-Telbany, F.; Stercho, Y. P. J. Org. Chem. 1984, 49, 2438. (b) Fisher, G. B.; Harrison, J.; Fuller, J. C.; Goralski, C. T.; Singaram, B. Tetrahedron Lett. 1992, 33, 4533. (c) Fisher, G. B.; Fuller, J. C.; Harrison, J.; Goralski, C. T.; Singaram, B. Tetrahedron Lett. 1993, 34, 1091. (d) Fisher, G. B.; Fuller, J. C.; Harrison, J.; Alvarez, S. G.; Burkhardt, E. R.; Goralski, C. T.; Singaram, B. J. Org. Chem. 1994, 59, 6378.

(5) Myers, A. G.; Yang, B. H.; Chen, H.; Gleason, J. L. J. Am. Chem. Soc. 1994, $116,9361$.

(6) Diastereomeric excesses (de's) of the alkylated pseudoephedrine amides were determined by capillary GC analysis of the corresponding $O$-trimethylsilyl ethers. Enantiomeric excesses (ee's) of the primary alcohols were determined by analysis of the corresponding Mosher ester derivatives (Dale, J. A.; Dull, D. L.; Mosher, H. S. J. Org. Chem. 1969, 34, 2543) by high resolution 'H NMR spectroscopy.

(7) (a) Pross, A.; Radom, L. Tetrahedron 1980, 36, 673. (b) Armstrong, D. R.; Perkins, P. G.; Walker, G. T. J. Mol. Struct. 1985, 122, 189.

(8) Srebnik, M.; Cole, T. E.; Veeraraghavan, R.; Brown, H. C. J. Org. Chem. 1989, 54, 6085.

(9) (a) Andrews, G. C.; Crawford, T. C. Tetrahedron Lett. 1980, 21, 693. (b) Andrews, G. C. Tetrahedron Lett. 1980, 21 , 697.

(10) Stetter, H.; Schwarz, M.; Hirschorn, A. Chem. Ber. 1959, 92, 1629.

(Received in USA 27 February 1996; revised 21 March 1996; accepted 28 March 1996) 